УДК 657: 658.62

\author{
Ю. В. Подмешальська, \\ к.е.н., дочент, дочент кафедри обліку, аналізу, оподаткування та аудиту, \\ Запорізький начіональний університет, м. Запоріжжя \\ ORCID ID: 0000-0001-6353-4542 \\ O. A. Скирдова, \\ магістрант кафедри обліку, аналізу, оподаткування та аудиту, \\ Запорізький начіональний університет, м. Запоріжжя \\ ORCID ID: 0000-0002-9862-4166
}

DOI: 10.32702/2306-6814.2021.21.93

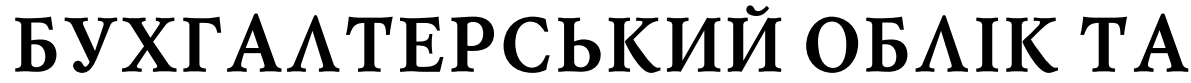 УПРАВ АІНЬКИЙ ОБАІК ВИРОБНИЧИХ ЗАПАСІB
}

\author{
Yu. Podmeshalska, \\ $\mathrm{PhD}$ in Economics, Associate Professor, Associate Professor of the Department of Accounting, \\ Analysis, Taxation and Audit, Zaporizhzhia National University, Zaporizhzhya \\ O. Skyrdova, \\ Master's student of the Department of Accounting, Analysis, Taxation and Audit, \\ Zaporizhzhia National University, Zaporizhzhya
}

\section{ACCOUNTING AND MANAGEMENT ACCOUNTING OF INVENTORIES}

Для раціональної організації бухгалтерського та управлінського обліку виробничих запасів суб'єктам господарювання необхідно чітко визначати завдання бухгалтерського та управлінського обліку, напрямки інформаційного, документального забезпечення для оперативного управління виробничими запасами на певних етапах обліку.

Перевага проведених досліджень полягає в розгляді облікових процедур бухгалтерського та управлінського обліку виробничих запасів у певній послідовності, а саме: від планування виробничих запасів в управлінському обліку, їх надходженні, використанні та визначені залишків виробничих запасів у бухгалтерському обліку не тільки на кінець звітного, а й протягом звітного періоду.

За результатами дослідження поточної та звітної інформації бухгалтерського обліку виробничих запасів, а також поточної, оперативної, звітної інформації, яку потребує управлінський облік для управління запасами у статті запропоновані практичні рекомендації щодо впровадження документального забезпечення оперативної інформації.

Для ефективного управління виробничими запасами важливезначення має визначення інформаційних потреб, термінів надання інформації та її документальне оформлення, тому у статті визначені інформаційне забезпечення господарських операцій та процедур обліку виробничих запасів, джерела інформації та відповідальні за надання необхідної інформації.

Забезпеченість виробничого процесу виготовлення готової продукції виробничими запасами одне із головних завдань управлінського обліку. Для виконання завдання необхідна оперативна інформація протягом звітного періоду про фактичне використання виробничих запасів, $i$ головне про фактичні залишки виробничих запасів. Запропонована методика формування та документального забезпечення необхідної інформації для управлінського обліку за даними бухгалтерського обліку, яка дозволяє отримати оперативну інформацію та корегувати поставки виробничих запасів. 
Запропоноване документальне забезпечення інформації для управлінського обліку має значення не тільки в її оперативності, але й ще виконує контрольні функції для аналізу і корегування управлінських рішень щодо управління виробничими запасами на виготовлення готової продукції.

For the rational organization of accounting and management accounting of inventories, businesses need to clearly define the tasks of accounting and management accounting, areas of information, documentation for the operational management of inventories at certain stages of accounting.

The advantage of the research is to consider the accounting procedures for accounting and management accounting of inventories in a certain sequence, namely: from the planning of inventories in management accounting, their receipt, use and determination of inventories in accounting not only at the end of the reporting but also during reporting period.

Based on the results of the study of current and reporting information of inventory accounting, as well as current, operational, reporting information required by management accounting for inventory management, the article offers practical recommendations for the implementation of documentation of operational information.

For effective management of inventories it is important to determine the information needs, deadlines for information and its documentation, so the article identifies information support of business operations and procedures for accounting for inventories, sources of information and responsible for providing the necessary information.

Provision of the production process of manufacturing finished products with production stocks is one of the main tasks of management accounting. To perform the task requires operational information during the reporting period on the actual use of inventories, and most importantly on the actual balances of inventories. A method of forming and documenting the necessary information for management accounting according to accounting data, which allows to obtain operational information and adjust the supply of inventories.

The proposed documentation of information for management accounting is important not only in its efficiency, but also performs control functions for the analysis and adjustment of management decisions on the management of inventories for the manufacture of finished products.

Ключові слова: бухгалтерський облік, управлінський облік, Виробничі запаси, Виробництво, документальне забезпечення, інформаційне забезпечення, готова продукція.

Key words: accounting, management accounting, inventories, production, documentation, information support, finished products.

\section{ПОСТАНОВКА ПРОБАЕМИ}

Процес управління виробничими запасами на підприємстві потребує наявності оперативного інформаційного забезпечення. Формування на підприємстві якісної та змістовної інформації щодо руху виробничих запасів в ході ведення обліку є запорукою прийняття ефективних управлінських рішень для безперебійного забезпечення виробничими запасами та створення умов для відсутності простоїв виробництва.

Відсутність оперативної та достовірної інформації про стан запасів на підприємстві впливає на швидкість коригування рівня виробничих запасів. Оперативна інформація, її повнота, достовірність впливають на якість контролю забезпеченості виробничими запасами, їх зберігання та використання. Дані бухгалтерського обліку виробничих запасів характеризують фрактичний рівень та рух запасів та $є$ недостатніми для ефективного управління ними.

На сьогодні в Україні питання, які пов'язані з управлінським обліком виробничих запасів на законодавчому рівні не регламентуються та для їх вирішення немає методичного забезпечення. При цьому організація управ- лінського обліку та його "взаємодія" з бухгалтерським обліком виробничих запасів $€$ актуальним питанням для суб'єктів господарювання. Одночасне ведення цих двох видів обліку дозволить вирішувати ряд важливих питань щодо забезпеченості оперативною інформацією управлінський персонал про стан виробничих запасів на підприємстві, що є актуальним та потребує вирішення.

\section{АНААIЗ ОСТ АНHIX АОС $А$ КЕНЬ \\ ТА ПУБАІКАЦІЙ}

Аналіз останніх досліджень і публікацій свідчить, що питання бухгалтерського та управлінського обліку запасів $€$ актуальними та розглядаються вченими й фрахівцями, серед яких: С.В. Голов, Ф.Ф. Бутинець, Н.М. Ткаченко, А.П. Макаренко, Т.О. Меліхова, Ю.В. Подмешальська, С.О. Левицька, О.М. Кудіна, Л.П. Кулаковська та інші. Автори, як правило, в публікаціях розглядають або тільки питання бухгалтерського обліку запасів, або управління запасами. Питання управлінського обліку виробничих запасів переважно розглядається в контексті питань управління запасами, витратами, матеріальними затратами. Питання "взаємодії" бухгалтерського та управ- 
Таблиця 1. Процедури бухгалтерського та управлінського обліку виробничих запасів на виготовлення готової продукції

\begin{tabular}{|c|c|c|}
\hline \multirow{2}{*}{$\begin{array}{c}\text { Основні } \\
\text { етапи обліку }\end{array}$} & \multicolumn{2}{|c|}{ Процедури } \\
\hline & Бухгалтерський облік & Управлінський облік \\
\hline 1 & 2 & 3 \\
\hline $\begin{array}{l}\text { Планування } \\
\text { виробничих } \\
\text { запасів }\end{array}$ & & $\begin{array}{l}\text { Складання бюджетів: } \\
\text { - реалізації готової продукції; } \\
\text { - виробництва готової продукції; } \\
\text { - придбання виробничих запасів; } \\
\text { - планування графіків поставок } \\
\text { виробничих запасів; } \\
\text { - контроль, аналіз поставок виробничих } \\
\text { запасів; } \\
\text { - корегування поставок за } \\
\text { необхідністю }\end{array}$ \\
\hline $\begin{array}{l}\text { Надходження } \\
\text { виробничих } \\
\text { запасів }\end{array}$ & $\begin{array}{l}\text { - Отримання та оплата рахунків-фактур; } \\
\text { - визнання отриманих запасів активами; } \\
\text { - оприбуткування запасів; } \\
\text { - визначення первісної оцінки запасів; } \\
\text { - організація синтетичного, } \\
\text { аналітичного, складського обліку } \\
\text { отриманих запасів }\end{array}$ & $\begin{array}{l}\text { - Організація контролю достовірності } \\
\text { отриманих запасів; } \\
\text { - організація контролю графіків } \\
\text { поставок запасів; } \\
\text { - контроль якості отриманих запасів; } \\
\text { - організація контролю і аналізу } \\
\text { забезпеченості виробничого процесу } \\
\text { виготовлення готової продукції } \\
\text { виробничими запасами }\end{array}$ \\
\hline $\begin{array}{l}\text { Використання } \\
\text { протягом } \\
\text { звітного } \\
\text { періоду }\end{array}$ & $\begin{array}{l}\text { - Облік руху і оцінка запасів; } \\
\text { - визначення фактичних виробничих } \\
\text { запасів на виготовлення готової } \\
\text { продукції; } \\
\text { - облік браку виробництва готової } \\
\text { продукції; } \\
\text { - організація документального } \\
\text { забезпечення відпуску, списання } \\
\text { виробничих запасів на виробництво } \\
\text { готової продукції; } \\
\text { - інформаційне забезпечення } \\
\text { управлінського персоналу для } \\
\text { прийняття управлінських рішень; } \\
\text { - організація контролю синтетичного та } \\
\text { аналітичного обліку виробничих } \\
\text { запасів; } \\
\text { - визначення залишків виробничих } \\
\text { запасів протягом звітного періоду; } \\
\text { - збір і обробка оперативної інформації } \\
\text { для потреб управлінського персоналу }\end{array}$ & $\begin{array}{l}\text { - Контроль ефективності і } \\
\text { раціональності використання } \\
\text { виробничих запасів; } \\
\text { - аналіз планових і фактичних даних } \\
\text { використання виробничих запасів; } \\
\text { - контроль і аналіз якості запасів на } \\
\text { брак у виробництві; } \\
\text { - контроль забезпеченості виробничими } \\
\text { запасами безперебійного процесу } \\
\text { виготовлення готової продукції; } \\
\text { - визначення необхідної оперативної } \\
\text { інформації, ії отримання, аналіз і } \\
\text { прийняття управлінських рішень }\end{array}$ \\
\hline Звітність & $\begin{array}{l}\text { - Баланс. } \\
\text { - Звіт про фінансові результати. } \\
\text { - Примітки до фінансової звітності }\end{array}$ & $\begin{array}{l}\text { - Внутрішні форми звітності } \\
\text { встановлюються суб’єктом } \\
\text { господарювання }\end{array}$ \\
\hline
\end{tabular}

бухгалтерського та управлінського обліку запасів. Серед яких те, що бухгалтерський облік виробничих запасів регламентований на законодавчо-нормативному рівні; має типові форми документального забезпечення обліку фрактів і операцій щодо руху виробничих запасів; має зовнішню звітність, в якій відображається інорормація про виробничі запаси. Організація управлінського обліку виробничих запасів залежить від професійності управлінського персоналу та досвіду облікових працівників суб'єкта господарювання.

Організація, методологія управлінського обліку визначається самостійно суб'єктом господарювання. Для ефективної організації управлінського обліку виробничих запасів необхідно встановити критерії доцільності інформації про виробничі запаси від їх планування, надходження, використання, визначення залишків виробничих запасів на початок та на кінець звітного періоду, визначити операції обліку та облікові процедури відповідно до їх реєстрації та відображення в бухгалтерському та управлінському обліку. Для визначення, розподілу облікових процедур пропонуємо поділити процес обліку виробничих запасів на певні етапи та визначити процедури

лінського обліку запасів, обміну інформацією, документального забезпечення відображення інформації окремо не розглядаються. В останній час багато публікацій присвячено управлінню запасами, де логістика $\epsilon$ пріоритетом. I якщо сучасний бухгалтерський облік запасів достатньо методологічно забезпечений, проблемних питань не так вже й багато, то цього не скажеш про управлінський облік запасів, який не регламентований на законодавчо-нормативному рівні, не має методологічного забезпечення та потребує досліджень.

\section{ВИК ААА ОСНОВНОГО МАТЕРІААУ}

Запаси, як один із видів активів суб'єкта господарювання, $є$ об'єктом бухгалтерського обліку та об'єктом управління в системі управлінського обліку. Для підвищення ефективності забезпечення та використання виробничих запасів необхідно визначити, яку інформацію саме управлінського чи бухгалтерського обліку виробничих запасів необхідно мати, в які терміни отримувати, в якій формі, кому надавати інфоормацію.

Для отримання відповідей на ці питання нами проведений аналіз основних складових щодо регламентації бухгалтерського та управлінського обліку на кожному $з$ них (табл. 1).

Узагальнюючи проведені дослідження щодо інформаційного забезпечення управління виробничими запасами у бухгалтерському та управлінському обліку необхідно:

- визначити послідовність операцій, процедур;

- визначити напрямки формування корисної та достовірної інфоормації про стан виробничих запасів;

- визначити документальне забезпечення інформаційних потоків;

- розробити грасріки документообігу;

— розробити внутрішню звітність з управлінського обліку виробничих запасів;

- врахувати основні механізми фоормування та передачі інформації для прийняття управлінських рішень. управлінського обліку виробничих запасів важливе значення має чіткий розподіл господарських операцій та облікових процедур між бухгалтерським і управлінським обліком. Вважаємо доцільним розглядати господарські операції та процедури бухгалтерського та управ-
Для ефективної організації бухгалтерського та 
Таблиця 2. Інформаційне забезпечення господарських операцій та процедур обліку виробничих запасів

\begin{tabular}{|c|c|c|c|c|}
\hline \multirow[b]{2}{*}{ № } & \multirow[b]{2}{*}{ Операції і процедури } & \multirow[b]{2}{*}{ Обмін інформацією } & \multicolumn{2}{|c|}{ Вид обліку } \\
\hline & & & $\begin{array}{l}\text { Бухгалтерський } \\
\text { облік }\end{array}$ & $\begin{array}{c}\text { Управлінський } \\
\text { облік }\end{array}$ \\
\hline 1 & 2 & 3 & 4 & 5 \\
\hline \multicolumn{5}{|c|}{ Організаційний етап } \\
\hline 1. & $\begin{array}{l}\text { Розробка внутрішнього Положення обліку виробничих } \\
\text { запасів }\end{array}$ & $\begin{array}{l}\text { Законодавчо-нормативні } \\
\text { акти, Методичні } \\
\text { рекомендації галузевих } \\
\text { Міністерств } \\
\end{array}$ & + & + \\
\hline 2. & $\begin{array}{l}\text { Визначення відповідальних для ведення обліку } \\
\text { виробничих запасів, розробка для них посадових } \\
\text { інструкцій }\end{array}$ & & + & + \\
\hline 3. & $\begin{array}{l}\text { Розробка робочого плану рахунків обліку виробничих } \\
\text { запасів }\end{array}$ & & + & + \\
\hline 4. & $\begin{array}{l}\text { Розподіл облікових операцій та проведення необхідних } \\
\text { процедур }\end{array}$ & & + & + \\
\hline 5. & $\begin{array}{l}\text { Розробка документів для відображення інформації за } \\
\text { формою, змістом, структурою }\end{array}$ & + & + & + \\
\hline 6. & Розробка графіку документообігу & + & + & + \\
\hline 7. & Вибір методу списання виробничих запасів & + & + & + \\
\hline 8. & $\begin{array}{l}\text { Розробка форм внутрішньої звітності з обліку } \\
\text { виробничих запасів }\end{array}$ & & & + \\
\hline 9. & $\begin{array}{l}\text { Підготовка інформації про стан виробничих запасів на } \\
\text { дату звітності для фінансової звітності }\end{array}$ & & + & \\
\hline \multicolumn{5}{|c|}{ Планування забезпеченості виробничими запасами для виготовлення готової продукції } \\
\hline 1. & Складання бюджету виробничих запасів & & & + \\
\hline 2. & Укладання договорів на поставку виробничих запасів & & & + \\
\hline 3. & Складання графіку поставок виробничих запасів & & & + \\
\hline 4. & Розрахунок калькуляції одиниці продукції & & & + \\
\hline 5. & Визначення планової потреби виробничих запасів & & & + \\
\hline \multicolumn{5}{|c|}{ Надходження виробничих запасів } \\
\hline 1. & $\begin{array}{l}\text { Проведення та облік розрахункових операцій по } \\
\text { придбанню виробничих запасів }\end{array}$ & + & $\begin{array}{l}\text { Сплата } \\
\text { рахунку- } \\
\text { фактури } \\
\end{array}$ & $\begin{array}{l}\text { Виписка } \\
\text { рахунку }\end{array}$ \\
\hline 2. & Оприбуткування виробничих запасів & + & + & \\
\hline 3. & $\begin{array}{l}\text { Контроль фактично одержаних виробничих запасів за } \\
\text { кількістю і ціною }\end{array}$ & + & + & + \\
\hline 4. & $\begin{array}{l}\text { Визначення первісної вартості одержаних виробничих } \\
\text { запасів }\end{array}$ & + & + & \\
\hline 5. & $\begin{array}{l}\text { Відображення одержаних виробничих запасів в } \\
\text { синтетичному та аналітичному обліку }\end{array}$ & & + & \\
\hline 6. & Організація складського обліку виробничих запасів & ++ & + & \\
\hline \multicolumn{5}{|c|}{ Використання виробничих запасів протягом звітного періоду } \\
\hline 1. & $\begin{array}{l}\text { Списання виробничих запасів на виготовлення готової } \\
\text { продукції }\end{array}$ & + & + & \\
\hline 2. & $\begin{array}{l}\text { Оцінка залишків виробничих запасів на певну дату з } \\
\text { урахуванням незавершеного виробництва }\end{array}$ & + & + & \\
\hline 3. & $\begin{array}{l}\text { Визначення фактичних виробничих запасів на } \\
\text { виготовлення готової продукції }\end{array}$ & + & + & \\
\hline 4. & $\begin{array}{l}\text { Контроль та аналіз використаних виробничих запасів на } \\
\text { виготовлення готової продукції протягом звітного } \\
\text { періоду }\end{array}$ & + & & + \\
\hline 5. & $\begin{array}{l}\text { Визначення, аналіз матеріальних затрат на } \\
\text { виготовлення готової продукції на дату фінансової } \\
\text { звітності }\end{array}$ & + & + & + \\
\hline 6. & Формування та надання іншої оперативної інформації & + & + & + \\
\hline \multicolumn{5}{|c|}{ Відображення інформації про стан виробничих запасів у звітності } \\
\hline 1. & $\begin{array}{l}\text { Визначення залишків виробничих запасів на дату } \\
\text { фінансової звітності }\end{array}$ & + & + & \\
\hline 2. & Аналіз використання виробничих запасів & + & & + \\
\hline 3. & $\begin{array}{l}\text { Відображення інформації про залишки виробничих } \\
\text { запасів у фінансовій звітності }\end{array}$ & + & + & \\
\hline 4. & $\begin{array}{l}\text { Відображення інформації про забезпечення, } \\
\text { використання, залишків на кінець звітного періоду у } \\
\text { внутрішній звітності }\end{array}$ & + & & + \\
\hline
\end{tabular}

лінського обліку за чітко визначеними етапами: організаційний, планування, надходження, використання, відображення у звітності з визначенням їх інформаційного забезпечення (табл. 2).
Запропонована методика визначення та розподілу процедур між бухгалтерським і управлінським обліком, $\epsilon$ початковим етапом процесу ефрективної організації бухгалтерського та управлінського обліку, може бути 
Таблиця 3. Відомість надходження виробничих запасів для виготовлення готової продукції за 2021 р.

\begin{tabular}{|c|c|c|c|c|c|c|c|c|c|c|}
\hline \multirow[b]{2}{*}{$\begin{array}{c}\text { Наймену- } \\
\text { вання } \\
\text { запасів }\end{array}$} & \multicolumn{4}{|c|}{ Управлінський облік } & \multicolumn{5}{|c|}{ Бухгалтерський облік } & \multirow{2}{*}{$\begin{array}{l}\text { Відхи- } \\
\text { лення } \\
\end{array}$} \\
\hline & $\begin{array}{c}\text { Запла- } \\
\text { нована } \\
\text { дата } \\
\text { поставки }\end{array}$ & К-сть & $\begin{array}{c}\text { Ціна, } \\
\text { грн }\end{array}$ & $\begin{array}{c}\text { Сума, } \\
\text { грн }\end{array}$ & $\begin{array}{c}\text { Номер } \\
\text { рахунку- } \\
\text { фактури, дата } \\
\text { оплати }\end{array}$ & $\begin{array}{c}\text { Дата } \\
\text { оприбуткування/ } \\
\text { № прибуткового } \\
\text { ордеру }\end{array}$ & К-сть & $\begin{array}{c}\text { Ціна, } \\
\text { грн }\end{array}$ & $\begin{array}{c}\text { Сума, } \\
\text { грн }\end{array}$ & \\
\hline 1 & 2 & 3 & 4 & 5 & 6 & 7 & 8 & 9 & 10 & 11 \\
\hline $\mathrm{A}$ & 30.03 & 200 кг & 15 & 3000 & № $35-01.04$. & 02.04.-№84 & 120 & 15 & 1800 & 1200 \\
\hline $\mathrm{A}$ & 15.04. & 100 кг & 18 & 1800 & № $42-12.04$ & 15.04.-№95 & 100 & 18 & 1800 & - \\
\hline$\ldots$ & & & & & & & & & & \\
\hline Paзом: & & 300 кг & $\bar{X}$ & 4800 & & & 220 & & 3600 & 1200 \\
\hline
\end{tabular}

використана суб'єктами господарювання на практиці при створенні управлінського обліку, а також для аналізу ефективності постановки управлінського обліку, який вже діє на підприємстві. Аналіз процедур дозволяє виявити корисність інформації, яка відображається в обліку, визначити додаткову іноормацію, яку необхідно зібрати, обробити, документально оформити та передати управлінському персоналу для прийняття управлінських рішень.

Відсутність методологічного забезпечення управлінського обліку ускладнює організацію управлінського обліку на підприємстві. На великих підприємствах розвиток управлінського обліку вже має свій досвід, а саме: сорормовані та діють центри відповідальності, налагоджена система документообігу, внутрішньої звітності. Тому запропоновані підходи до організації управлінського обліку з боку практичного використання будуть більш цікаві середньому бізнесу.

Бухгалтерський та управлінський облік виробничих запасів тісно пов'язані між собою й рахунками обліку, й документальним забезпеченням господарських операцій, й обміном інформацією про результати здійснених операцій, й визначенням фінансових результатів діяльності.

Для більш ефективної "взаємодії" бухгалтерського та управлінського обліку виробничих запасів має значення створення відповідних внутрішніх документів, які забезпечать обмін корисною, достовірною інформацією, графріків документообігу цих документів, визначення відповідальних за створення та обробку документів, що в свою чергу буде сприяти раціональній організації обліку виробничих запасів, скороченню часу на їх підготовку та таким чином підвищить ефективність використання виробничих запасів.
Слід зазначити, що саме в ході ведення управлінського обліку здійснюються планові розрахункові процедури для визначення забезпеченості та використання виробничих запасів, далі заплановані показники передаються в бухгалтерію, тобто інформаційне забезпечення розпочинається з управлінського обліку. На цьому етапі необхідно визначити перелік, форму, зміст, строки надання, відповідальних щодо документального забезпечення бухгалтерського обліку плановими показниками.

Управління виробничими затратами розпочинається із складання бюджетів виробництва готової продукції, бюджетів виробничих запасів, графріків поставок виробничих запасів. Бухгалтерський облік виробничих запасів розпочинається з моменту отримання рахунківфактури, їх оплати, оприбуткування виробничих запасів. Контроль надходження виробничих запасів здійснює управлінський облік на підставі інфрормації бухгалтерського обліку.

Для контролю та аналізу поставок виробничих запасів доцільно відображати необхідну інформацію для управлінського обліку у відповідній відомості, мета якої - забезпечення достовірною інфрормацією управлінський облік про фактичні надходження виробничих запасів на виготовлення готової продукції, первісну вартість отриманих виробничих запасів, яка включає не тільки ціну запасів, а й додаткові витрати, які включаються до первісної вартості та залежать від дій та рішень управлінського персоналу.

Управлінський облік виконує функцію контролю за забезпеченістю виробничого процесу виготовлення готової продукції виробничими запасами. Відповідно до складених бюджетів в ході ведення управлінського обліку контролюється виконання графріків поставок вироб-

\section{Таблиця 4. Напрями використання Відомості надходження виробничих запасів} для контролю та аналізу

\begin{tabular}{|c|c|c|}
\hline $\begin{array}{l}\text { Джерело інформації } \\
\text { (графа Відомості) }\end{array}$ & Бухгалтерський облік & Управлінський облік \\
\hline $\begin{array}{l}\text { Підсумок графи } \\
10 \text { - фактична вартість } \\
\text { отриманих виробничих } \\
\text { запасів }\end{array}$ & $\begin{array}{l}\text { Контроль інформації: } \\
\text { - за дебетом рахунка } 63 \text { - погашення кредиторської } \\
\text { заборгованості; } \\
\text { - за кредитом рахунка } 31 \text { - сплата грошових коштів; } \\
\text { - достовірність інформації прибуткового ордеру за } \\
\text { кількістю отриманих виробничих запасів, ціни } \\
\text { придбання. }\end{array}$ & \\
\hline Графа 2 і Графа 6 & & $\begin{array}{l}\text { Контроль строків поставок: } \\
\text { Графік поставок - фактична дата } \\
\text { надходження виробничих запасів }\end{array}$ \\
\hline Графа 4 і Графа 9 & & $\begin{array}{l}\text { Аналіз і контроль ціни одиниці виробничих } \\
\text { запасів }\end{array}$ \\
\hline Графа 3 і Графа 8 & & $\begin{array}{l}\text { Аналіз і контроль плану і фактичних } \\
\text { поставок в кількісному вимірі }\end{array}$ \\
\hline
\end{tabular}


Таблиця 5. Джерела інформації для розрахунку залишків виробничих запасів на кінець звітного періоду

\begin{tabular}{|c|c|c|c|}
\hline Інформація & Джерело інформації & Період визначення & Відповідальний \\
\hline 1 & 2 & 3 & 4 \\
\hline $\begin{array}{l}\text { Залишки на кінець звітного } \\
\text { періоду }\end{array}$ & $\begin{array}{l}\text { Дебетове сальдо рахунка } 20 \\
\text { (відповідний аналітичний рахунок) }\end{array}$ & Кінець звітного періоду & Бухгалтер-матеріаліст \\
\hline $\begin{array}{l}\text { Залишки на початок звітного } \\
\text { періоду }\end{array}$ & $\begin{array}{l}\text { Залишок на кінець звітного періоду } \\
\text { Сальдо дебетове рахунку } 20 \\
\text { (відповідний аналітичний рахунок) }\end{array}$ & Початок звітного періоду & Бухгалтер-матеріаліст \\
\hline $\begin{array}{l}\text { Надходження виробничих } \\
\text { запасів протягом звітного } \\
\text { періоду }\end{array}$ & $\begin{array}{l}\text { Дебет рахунку } 20 \\
\text { (відповідний аналітичний рахунок) }\end{array}$ & В момент оприбуткування & $\begin{array}{l}\text { Бухгалтер-матеріаліст, } \\
\text { Бхгалтер-аналітик }\end{array}$ \\
\hline $\begin{array}{l}\text { Фактичні матеріальні запаси } \\
\text { на виготовлення готової } \\
\text { продукції }\end{array}$ & Дебет рахунку 23 & $\begin{array}{l}\text { В момент списання готової } \\
\text { продукції на склад, } \\
\text { замовнику }\end{array}$ & $\begin{array}{l}\text { Відповідний структурний } \\
\text { підрозділ }\end{array}$ \\
\hline Забраковані виробничі запаси & Акт забракованих запасів & В момент виявлення & Виробничий підрозділ \\
\hline $\begin{array}{l}\text { Виробничі запаси у } \\
\text { незавершеному виробництві }\end{array}$ & $\begin{array}{l}\text { Дебетове сальдо рахунку } 23 \text { після } \\
\text { списання готової продукції }\end{array}$ & $\begin{array}{l}\text { Після списання готової } \\
\text { продукції }\end{array}$ & Виробничий підрозділ \\
\hline
\end{tabular}

Таблиця 6. Оперативна відомість для визначення залишків виробничих запасів за квітень місяць 2021 р.

\begin{tabular}{|c|c|c|c|c|c|c|c|}
\hline Період & $\begin{array}{c}\text { Назва } \\
\text { запасів }\end{array}$ & $\begin{array}{c}\text { Фактичний } \\
\text { залишок на } \\
\text { початок періоду }\end{array}$ & $\begin{array}{c}\text { Надходження } \\
\text { Дата/ К-сть }\end{array}$ & $\begin{array}{c}\text { Фактично } \\
\text { використані } \\
\text { виробничі запаси на } \\
\text { виготовлення ГП }\end{array}$ & $\begin{array}{c}\text { Забраковані: } \\
\text { неякісні / брак у } \\
\text { виробництві }\end{array}$ & $\begin{array}{c}\text { Запаси } \\
\text { у НЗВ } \\
\text { на кінець } \\
\text { періоду } \\
\end{array}$ & $\begin{array}{c}\text { Фактичний } \\
\text { залишок на } \\
\text { кінець періоду }\end{array}$ \\
\hline 1 & 2 & 3 & 4 & 5 & 6 & 7 & 8 \\
\hline \multicolumn{8}{|c|}{ Код готової продукції } \\
\hline \multirow{2}{*}{$\begin{array}{l}1.04 .- \\
10.04 .\end{array}$} & A & 300 кг & 2.04. - 120 кг & 250 кг & 10 кг & 120 кг & 280 кг \\
\hline & Б & 200 кг & 4.04. - 200 кг & 100 кг & - & 50 кг & 350 кг \\
\hline \multirow{3}{*}{$\begin{array}{l}\ldots . \\
11.04 .- \\
20.04 .\end{array}$} & & & & & & & \\
\hline & A & 180 кг & 15.04.- 100 кг & 120 кг & 20 кг & 80 кг & 220 кг \\
\hline & Б & 350 кг & - & 130 кг & - & 60 кг & 280 кг \\
\hline$\ldots$ & & & & & & & \\
\hline
\end{tabular}

ничих запасів за даними бухгалтерського обліку. Тобто інорормація бухгалтерського обліку відображає фрактичні поставки виробничих запасів на рахунках обліку на підставі первинних документів. Враховуючи те, що для управлінського обліку забезпеченість виробничими запасами визначається їх кількісним визначенням, тому у статті інорормація про стан виробничих запасів на виготовлення готової продукції також розглядається в кількісному вимірі.

Вважаємо доцільним для оперативного інформування управлінський персонал про фрактичні надходження виробничих запасів вести Відомість надходження виробничих запасів протягом звітного періоду (табл. 3).

Відомість розпочинає заповнювати бухгалтер-аналітик з відділу управлінського обліку відповідно до затверджених бюджетів і надає в бухгалтерію на перше число наступного місяця. Протягом місяця бухгалтерія заповнює другу частину відомості та управлінський персонал у будь-який момент може провести аналіз поставок. Електронний варіант Відомості дозволяє здійснювати контроль надходження виробничих запасів протягом місяця без зайвого витрачання часу на отримання інформації, оперативно реагувати на порушення строків поставок.

За інформацією запропонованої Відомості пропонується контролювати дані про надходження виробничих запасів для виготовлення готової продукції, а також достовірність оприбуткування отриманих виробничих запасів (табл. 4).

Після оприбуткування виробничих запасів бухгалтерія розпочинає синтетичний та аналітичний облік от- риманих виробничих запасів. Відповідно до Плану рахунків бухгалтерського обліку для обліку запасів використовуються рахунки класу 2 "Запаси". Інформація за рахунками 20 "Виробничі запаси" та 23 "Виробництво" використовується в управлінському обліку для аналізу забезпеченості виробництва запасами на виготовлення готової продукції, тому інформація повинна бути оперативною та достовірною. Носії інформації щодо розрахунку рівня залишків виробничих запасів на кінець звітного періоду систематизовані в таблиці 5 .

Таким чином, для отримання достовірної оперативної інфрормації про фрактичні залишки виробничих запасів для виготовлення готової продукції, яка необхідна управлінському персоналу для контролю та управління виробничими запасами, в системі управлінського обліку необхідно зібрати інформацію, яка наведена в таблиці 4. Пропонуємо Оперативну відомість для визначення залишків виробничих запасів" на певну дату (табл. 6).

Заповнення запропонованої відомості здійснюють відповідальні особи протягом періоду в моменти здійснення відповідних господарських операцій, контроль і відповідальність за достовірність інформації покладається на бухгалтера-матеріаліста.

Основне призначення Оперативної відомості полягає у визначенні достовірної інфрормації про залишок виробничих запасів на виготовлення готової продукції на певну дату з урахуванням залишків запасів у незавершеному виробництві та виявлених забракованих запасів, саме тому, що дебетове сальдо відповідних субрахунків рахунку 20 їх не враховує, а тому не відобра- 
Таблиця 7. План закупок виробничих запасів на виготовлення готової продукції

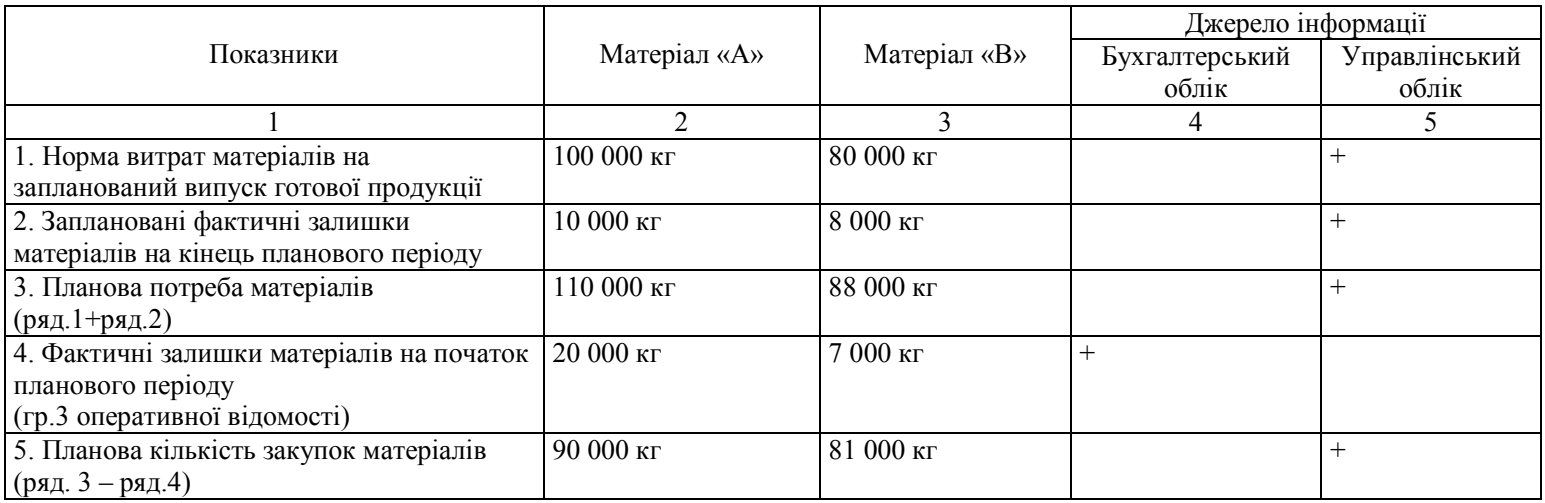

жає достовірну інфрормацію про залишок запасів на певну дату.

Інформація графри 8 - це саме та інфрормація, яку потребує управлінський облік для ефективного управління забезпеченням виробничих запасів на виготовлення готової продукції.

Слід зазначити, що запропонована Оперативна відомість містить інфрормацію й про використані виробничі запаси у виробництві, й про фактичні залишки виробничих запасів. Це означає, що запропонована Оперативна відомість містить корисну, достовірну інфрормацію, яку необхідно використовувати управлінському персоналу для планування закупок виробничих запасів та їх коригування.

Взаємозв' язок між інформацією бухгалтерського та управлінського обліку при плануванні закупок виробничих запасів наведено у вигляді таблиці 7.

Таким чином, використання графр запропонованої оперативної відомості дозволить контролювати наступні показники:

- графра 4: надходження виробничих запасів в кількісному вимірі повинно дорівнювати кількості виробничих запасів у рахунках-орактурах та в прибуткових ордерах; дати поставок повинні відповідати графрікам поставок;

- графра 5: для контролю нормативного використання виробничих запасів; для контролю матеріальних затрат;

- графра 8: для контролю дебетового сальдо рахунку 20 на звітну дату.

Крім цього, важливим моментом $є$ те, що інфрормація запропонованої відомості може використовуватися для аналізу структури матеріальних затрат за видами готової продукції. Оскільки необхідна інфрормація для аналізу вже визначена, згрупована, обчислена та не потребує додаткового часу для її збирання, обробки.

\section{ВИСНОВКИ}

У статті у логічній послідовності розглянуті основні аспекти бухгалтерського, управлінського обліку виробничих запасів на виготовлення готової продукції. Для ефективної організації "взаємодії" бухгалтерського та управлінського обліку виробничих запасів визначені основні облікові процедури бухгалтерського та управлінського обліку виробничих запасів, які необхідно враховувати для організацію обліку виробничих запасів. Запропонований варіант розподілу облікових процедур між бухгалтерським і управлінським обліком для ви- значення потоку інформаційного забезпечення управлінського персоналу.

Запропоновані форми документального забезпечення оперативною інформацією управлінського персоналу задля ефективного управління виробничими запасами в розрізі їх плануванні, коригуванні протягом звітного періоду. Результати досліджень можуть бути використані суб'єктами господарювання в практичній діяльності.

Література:

1. Макаренко А.П., Меліхова Т.О., Подмешальська Ю.В., Чакалова Н.С. Бухгалтерський облік: навч.-метод. посібник. Запоріжжя: ЗДІА, 2018. 602 с.

2. Меліхова Т.О., Чакалова Н.С., Мисливка К.А. Удосконалення обліку доходів від реалізації товарів, як інструмент ефективного управління підприємством. Ефективна економіка. 2019. № 2. URL: http:// www.economy.nayka.com.ua/?op=1\&z=6888 (дата звернення: 11.11.2020). DOI: 10.32702/2307-2105-2019.2.38.

3. ПодмешальськаЮ.В., Парнюк О.В. Документальне забезпечення обліку товарних запасів на підприємстві. Агросвіт. 2020. № 22. C. 97-104. DOI: 10.32702/2306-6792.2020.22.97.

4. Подмешальська Ю.В., Понякіна К.Ю. Облік та аудит виробничих витрат на підприємстві. Інвестиції: практика та досвід. 2020. № 23. C. 64-70. DOI: 10.32702/2306-6814.2020.23.64.

References:

1. Makarenko, A.P. Melikhova, T.O. Podmeshalska, Y.V. and Chakalova, N.S. (2018), Bukhhalters'kyy oblik [Accounting], ZDIA, Zaporizhzhya, Ukraine.

2. Melikhova, T. O., Chakalova, N. S. and Myslyvka, K. A. (2019), "Improving the account of income from the implementation of goods, as a tool of effective management of the enterprise", Efektyvna ekonomika, [Online], vol. 2, available at: http:/ / www.economy.nayka.com.ua/ ?op $=1 \& z=6888$ (Accessed 11 Nov 2020). DOI: 10.32702/ 2307-2105-2019.2.38.

3. Podmeshalska, Yu. and Parniuk, O. (2020), "Documentary accounting of inventories at the enterprise", Agrosvit, vol. 22, pp. 97-104. DOI: 10.32702/23066792.2020.22.97.

4. Podmeshalska, Yu. and Poniakina, K. (2020), "Accounting and audit of production costs at the enterprise", Investytsiyi: praktyka ta dosvid, vol. 23, pp. 6470. DOI: 10.32702 /2306-6814.2020.23.64.

Стаття надійшла до редакиї 29.10.2021 p. 